\title{
Lewensgemeenskap met God as essensie van Bybelse spiritualiteit
}

\section{ABSTRACT}

A B du Toit

\section{Living communion with God as essence of biblical spirituality}

Our age experiences an urgent need for real spirituality. This anticle is intended as a further contribution to the local discussion on this topic. Life-long communion with God is highlighted as the essence of biblical spirituality, although the Bible contains different traditions and types in this regard. The most important aspects of this living fellowship with God is the praesentia Dei, the relational framework within which it takes place, metaphors reflecting its existence, specific moments of meeting with God, and its ethical and eschasological edges.

\section{$1 \quad$ INLEIDEND}

Ons tyd beleef ' $n$ ontsaglike behoefte aan ware spiritualiteit. Onder spiritualiteit word verstaan 'n lewenskwaliteit wat hom eerstens in 'n bepaalde geestelike ingesteldheid en diepgang manifesteer, wat hom tweedens in kenmerkende geestelikgodsdienstige gestaltegewings uitdruk en derdens 'n spesifieke stempel op die betrokkenes se lewenstyl (etiek) afdruk 1 .

Hierdie diepe behoefte aan spiritualiteit blyk byvoorbeeld uit die ontploffing ten opsigte van populêre en wetenskaplike publikasies oor hierdie onderwerp². Interessant genoeg wys Jonker daarop dat Andrew Murray se werke weer besondere a andag geniet ${ }^{3}$. So pas is ook 'n nuwe internasionale tydskrif oor spiritualiteit aangekondig ${ }^{4}$.

Gemelde behoefte aan spiritualiteit blyk nog verder uit die beweging van baie Christene vanuit gevestigde kerke na charismatiese groepe, in die hoop om aldaar ware spiritualiteit te beleef. Selfs in die sogenaamde post-Christelike Europa soek mense voedsel vir die gees in transendentale meditasie, by die Islam, ensomeer. Ook vir die moderne mens is vroomklinkende agendas vir oikologiese, sosiale, ekonomiese en politieke hervorming nie genoeg nie.

Die belangrikste rede vir hierdie nood lè by die materialisme van ons tyd, wat 'n ontstellende "godsverduistering" meegebring het. Ons denke is vasgevang in 'n antimetafisiese keurslyf; ons teologie en vroomheid word verhorisontaliseer; die klem val op die fisiek-voorhandene, die liggaamlike, die seksuele. Hierdie materialistiese ingesteldheid is soos ' $n$ soort vigs van die gees. Dit laat die geestelike dimensie wegkwyn. Ook kerke, pastorieë en teologiese fakulteite spring hierdie geestelike agteruitgang nie vry nie. En waar die geestelike dimensie nog wel behoue gebly het, vier 'n aktiwistiese "Marta-vroomheid" dikwels hoogty ten koste van die "beste deel" van die "Maria-vroomheid". 'n Tweede belangrike rede vir hierdie nood van ons tyd is die onvermoë van gevestigde kerke om uit die greep van formalistiese verstarring te breek.

Hierdie artikel is bedoel as 'n aanvullende bydrae tot die plaaslike gesprek oor spiritualiteit. Van die bogenoemde drie fasette van spiritualiteit word 
hoofsaaklik aan die eerste een aandag gegee, en dan veral aan wat beskou kan word as die kern van Bybelse spiritualiteit.

Die formulering "Bybelse spiritualiteit" is op sigself reeds te bevraagteken. Ons kry in die Skrif immers nie een homogene verskynsel wat "Bybelse spiritualiteit" genoem kan word nie, maar 'n verskeidenheid manifestasies van spiritualiteit wat geensins klone van mekaar is nie. Vroomheidspatrone soos gereflekteer in die onderskeie Ou-Testamentiese tekste en tradisies is geensins identies nie. Dieselfde is ook die geval in die Nuwe Testament, al verteenwoordig hierdie tekste 'n veel korter ontstaanstydperk. Die Pauliniese, die Petriniese, die Matteaanse, die Lukaanse en die Johannese vroomheid het elk hulle eie, tipiese kenmerke. Nietemin is daar een samebindende trajek wat herkenbaar deur al die belangrikste manifestasies van Bybelse spiritualiteit loop: dié van lewensgemeenskap met God. Hierdie trajek maak na my oordeel die wese uit van Bybelse spiritualiteit. In wat volg, word slegs die belangrikste kontoere van hierdie insig uitgelig. Hoe langer my navorsing op hierdie onderwerp voortgegaan het, hoe meer het ek besef dat veel dieper op haas elke gesigspunt ingegaan behoort te word.

BELANGRIKSTE KONTOERE VAN DIE LEWENSGEMEENSKAP

\section{MET GOD}

\subsection{Die Praesentia Dei}

Lewensgemeenskap met God veronderstel die moontlikheid van kontak met Hom. Kontak met God konfronteer ons op sy beurt met die vraag na die teenwoordigheid en toeganklikheid van God.

Die Ou-Testamentiese bronne het veel oor die verborgenheid en die geheimenis van God te sê5. Terselfdertyd word egter ook baie gemaak van God se teenwoordigheid onder sy volk en die moontlikheid om 'n ontmoeting met Hom te hê. Al is Hy oral teenwoordig (vergelyk bv Ps 139), ontmoet Hy mense deur Hom op bepaalde maniere en op bepaalde plekke te openbaar. Om hierdie rede is teoretiese ateïsme nie 'n werklike Bybelse probleem nie, praktiese ateïsme wel. Ook Psalms 14 en 53 lê nie op die vlak van 'n teoretiese ontkenning van die bestaan van God nie, maar op dié van 'n nie-rekening-hou met God en 'n volslae "diesseitige" gerigtheid6. Van hierdie praktiese materialisme, waarvan die Bybel vol is, en wat deur die begrip "dwaasheid" uitgedruk word, is die "ryk dwaas" van Lukas 12:1621 natuurlik'n klassieke voorbeeld?

'n Baie belangrike Ou-Testamentiese metafoor wat hier ons aandag vra, is dié van God se "aangesig". In talle Ou-Testamentiese kontekste dui hierdie metafoor op God se persoonlike teenwoordigheid. So beteken die uitspraak dat God se "aangesig" moet meetrek om aan Moses die rusplek te verskaf (Eks 33:14) niks anders as dat God self, met sy persoonlike teenwoordigheid, sy volk moet begelei nie 8 . Netso kan die uitdrukking "van aangesig tot aangesig" dui op 'n persoonlike ontmoeting tussen God en bepaalde persone (Gen 32:30; Eks 33:11; Deut 5:4; 34:10; Rigt 6:22; Eseg 20:35).

Die Ou-Testamentiese skrywers is dus nie net bewus daarvan dat Jahwe oral is nie, hulle weet ook heel sterk van God se intrede in die lewens van mense. Afgesien van die hesondere wyse waarop Israel met God gekonfronteer is in die aanspreke deur sy woorde, was die plek war $\mathrm{Hy}$ by uitnemendheid die mens 
ontmoet het, dic kultus. Daarom word die metafoor "aangesig van God" en die semanties verwante term "voor Jahwe" heel besonderlik aan die heiligdom verbind". Om "voor God/die Here se aangesig" of "voor die Here" te verskyn, dui by uitstek op die belewenis van God se heilige en genadevolle teenwoordigheid in die heiligdom (bv Eks 23:15,17; 28:35; 34:23; Deut 16:16; 31:11; Rigt 20:26; 1 Sam 13:12; ens) ${ }^{10}$. Wanneer God sy "aangesig verberg" beteken dit dat Hy sy gemeenskap as gevolg van menslike sonde onttrek (Deut $31: 17 ; 32: 30$; Jes 8:17; 54:8; ens) ${ }^{11}$, terwyl uitdrukkings soos "God/Jahwe se aangesig soek" of "Jahwe soek" dui op die begeerte en die aksie om die lewensverbondenheid met Hom te herstel (2 Sam 21:1; Jes 26:9; Hos 3:5; 5:6,15; 7:10; Ps 24:6; ens).

Die gelowige se hele bestaan is dus ' $n$ "wandel voor die aangesig van God" (vgl Gen 17:1; 24:40; 48:15; Deut 1:30,33; 1 Sam 2:30,35; ens), maar dit is in besonder in die heiligdom dat hy God se nabyheid intens beleef. Hierdie heerlike ervaring van die lewensgemeenskap met God in sy heiligdom was vir die Israelitiese vrome die belangrikste saak in sy lewe, die summum bonum. Psalm 27 druk hierdie oortuiging op aangrypende wyse uit (veral v 4-6; vergelyk ook Ps 16:2 en Ps 73:2528). Psalm 42 druk die gelowige se smagte na God uit met die beeld van 'n dors na water terwyl Psalm 84 die lieflikheid van God se woning in roerende taal besing. Hier het ons Bybelse spiritualiteit op sy suiwerste.

Die verbinding van die heiligdom met die verskyning van "die heerlikheid van die Here" (Eks 24:16; 29:43; 40:34-35; 1 Kon 8:11; ens) was 'n ander manier om die idee van God se koms na sy volk te verwoord ${ }^{12}$. Dit is veelbetekenend dat die Nuwe Afrikaanse Vertaling hierdie uitdrukking telkens vertaal met "die magtige teenwoordigheid van die Here".

Hierdie selfde gedagte van die heiligdom, in hierdie geval die tabernakel, as ontmoetingspunt tussen God en sy volk, word treffend uitgedruk deur die benaming "tent van ontmoeting" (Eks 27:21; 28:43; 29:4,10,11; ens).

Ook die woonmotief was 'n besonder geskikte metafoor om die gedagte van God se persoonlike nabyheid uit te druk ${ }^{13}$. God woon nie net in die hemel nie (Ps 2:4; 113:5; Jes 33:5; 57:15); Hy woon ook onder sy volk (Eks 25:8; 29:45-46; Num 5:3; ens) en op die berg Sion (Jes 8:18; Joël 3:17,21; Sag 8:3; ens). Die gedagte van die heiligdom as die "woning" of "huis" van God/die Here sluit natuurlik direk hierby aan (Ps 43:3; 78:60; 79:7; 84:2; ens). In die Jodedom sou die Schekinamotief, wat die woonidee verder voer, heel gebruiklik word om God se aardse teenwoordigheid aan te dui ${ }^{14}$.

Van die vroegste tye af is egter anvaar dat God oral toeganklik is vir wie Hom aanroep. Daarom was die gebed geensins tot die heiligdom beperk nie. Daarom kry ons vanaf die vroegste Ou-Testamentiese tekste tot in die Apokriewe, naas die gebede in die heiligdom, ook gebede wat elders uitgespreek word ${ }^{15}$. Die verwoesting van die tempel en die verwyderdheid daarvan in die diaspora het begryplikerwys die beoefening van laasgenoemde gebede sterk gestimuleer. In Daniël se gebed (Dan 6:11) speel die rigting na die heiligdom 'n belangrike rol. In Nehemia se gebed "voor die aangesig van die God van die hemel" speel die heiligdom egter geen aanwysbare rol nie. Waar die bidder ook al God mag aanroep, daar kan hy "die aangesig van God" teëkom, dit wil sê in 'n persoonlike ontmoeting ncet God kom. Tog wys Westermann tereg daarop dat in hierdie tydvak, na die groot krisis van die ballingskap, sondebewustheid en die besef van 'n groter-geworde afstand tussen God en die bidder aan die orde van die dag is ${ }^{16}$. 
Die Nuwe-Testamentiese oortuiging van God se onbeperkte toeganklikheid word duidelik uit die feit dat verreweg die meeste gebede nou nie meer tempelgebonde is nie. Die klassieke formulering van hierdie nuwe fase kry ons in die Johannesevangelie: "Jesus sê vir haar (die Samaritaanse vrou): Glo My, Mevrou, daar kom 'n tyd wanneer julle die Vader nie op hierdie berg en ook nie in Jerusalem sal aanbid nie... daar kom 'n tyd, en dit is nou, wanneer die ware aanbidders die Vader in Gees en waarheid sal aanbid... God is Gees, en die wat Hom aanbid, moet Hom in Gees en waarheid aanbid" (4:21, 23-24).

Met die opheffing van die belang van die tempel is dit begryplik dat die woonmotief nou vergeestelik word. Die gemeente van Christus (1 Kor 3:16-17; 2 Kor 6:16; Efes 2:21), sowel as die liggaam van die individuele gelowige (1 Kor 6:19), word nou 'n tempel van God, met ander woorde, 'n konsentrasiepunt van God se gemeenskap met die mense.

Op aangrypende manier omskep Johannes die woonmotief christologies:

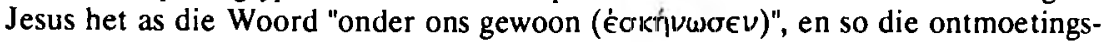
punt tussen God en die mense geword (1:14; vgl ook v 18).

Die woonmotief keer in eind-eskatologiese perspektief in die boek Openbaring terug. In die nuwe Jerusalem "woon" God self by sy mense (21:3). God se tabernakel is nou weer by die mense, maar met een verskil: Die insidentele karakter van vroeëre ontmoetings tussen God en sy mense het nou oorgegaan na 'n deurlopende, volmaakte gemeenskapsbelewenis.

\section{$2.2 \quad$ Binne 'n relasionele raamwerk}

Lewensgemeenskap met God vind in sowel die Ou as die Nuwe Testament binne 'n relasionele raamwerk plaas, waarin God se soewereine vrymag, inisiatief, genade en liefde vooropstaan. Hierdie stelling word nou toegelig aan die hand van ' $n$ aantal metafore wat prominent funksioneer.

Die bekendste Bybelse metafoor in hierdie verband, is uiteraard dié van die verbond. Die Ou-Testamentiese teologie van Eichrodt ${ }^{17}$ is tereg gekritiseer omdat die verbond hier te sterk as allesoorheersende beginsel funksioneer. Dit hoef egter nie hier beredeneer te word dat die verbond in elk geval 'n uiters belangrike rol in Israel se denke en vroomheid gespeel het nie ${ }^{18}$. In die Nuwe Testament is die verbondsdenke minder prominent, maar geensins onbelangrik nie. Slegs die belangrikste aanduidings van verbondsdenke word hier aangestip: Dit is prominent in die nagmaalwoorde ( $M k$ 14:22-25 par). By Paulus moet, afgesien van sy nagmaaloorlewering (1 Kor 11:23-26), ook nog op 2 Korintiërs 3:6 en Galasiërs 3:15-20 gewys word. En in Hebreërs funksioneer die verbond heel sterk ${ }^{19}$.

Die Ou-Testamentiese verbondsdenke is geensins so homogeen as wat dikwels aanvaar word nie. Daar was verskillende verbondsluitinge en verskillende aksentleggings, waarin die mens se rol as verbondspartner gewissel het ${ }^{20}$. Tog word die verbond nooit ten volle dipleuries nie. Deurgaans oorheers die oortuiging dat dit God (Jahwe) is wat in genadige en soewereine toewending 'n blywende verhouding met sy volk skep 21 . Die Abrahamverbond, waarvan in Genesis 12 en volgende berig word, moet gesien word as God se genadige en soewereine nuwe begin na die chaotiese Godsvervreemding waarvan in die voorafgaande hoofstukke berig word. Hierdie blywende verhouding was die deur God in liefde daargestelde regsgrond en 
ruimte waarbinne Hy sy volk ontmoet en "n gemeenskapsverhouding ontstaan het, waarvan die hoogste belewenis by die kultus plaasgevind het 22 .

Die Goddelike inisiatief staan ook in die Nuwe-Testamentiese verbondsdenke op die voorgrond. Dit is Jesus wat met die instellingswoorde van die Nagmaal die nuwe verbond (só 1 Kor 11:25 par Lk 22:20) inisieer en aan die eskatologiese Godsvolk deur brood en wyn daaraan aandeel gee. In Galasiërs 3:15 besit die verbond 'n volledige monopleuriese karakter. Ook in Hebreërs staan God se soewereine optrede voorop (vgl Heb 8:8-13; $9: 20 ; 10: 16 \mathrm{v}$ ). Die nuwe verbond moet dus verstaan word as synde die nuwe verhoudingswerklikheid wat deur God se liefdesdaad aan die kruis tot stand gekom het, en waarbinne die gelowiges opnuut lewensgemeenskap met God mag beleef.

'n Tweede prominente Bybelse metafoor wat die relasionele aspek beklemtoon, is dié van 'n huweliksverhouding tussen God en sy volk. In wese lê dit na aan die verbondsmotief, omdat die huwelik ook as 'n verbond beskou kan word (Mal 2:14, vgl Spr 2:17). Hierdie metafoor figureer meermale in die profetiese literatuur (Hos 1-3; Jer 2-3; Eseg 16,23; Jes 50:1). Ook hier staan God se inisiatief voorop, soos blyk uit sy beslissende posisie as die bruidegom. God se genadige, verkiesende handeling blyk besonder aangrypend uit die roerende beskrywing in Esegiël 16. Maar die gesigspunt wat in hierdie verhouding die sterkste na vore tree, is die van God se troue liefde ten spyte van Israel se ontrou. Veral Hosea skilder hierdie liefde van God op roerende wyse.

In die Nuwe-Testamentiese gebruikmaking van hierdie metafoor (veral 2 Kor 11:2, Ef 5:21-32; Op 19:7-9; 21:2,9; 22:17) staan Christus as Bruidegom voorop, maar ook hier is die inhoudelike vulling met die liefde, kragtens die eie aard van hierdie beeld, die mees prominente gesigspunt (vgl Ef 5:25,29).

Ten opsigte van beide bogenoemde metafore is dit belangrik om die probleem van die individualistiese of kollektiewe karakter van spiritualiteit aan die orde te stel. In albei gevalle gaan dit duidelik om 'n verhouding van God tot sy volk as geheel. Die Israelitiese spiritualiteit, wat binne hierdie verhouding ingebed was, kon dus geensins bloot individualisties gewees het nie. Spiritualiteit is korporatief beleef. Hierdie korporatiewe inslag sluit egter nie die individu uit nie, maar juis in. Sy individualistiese vroomheidsbelewenis staan egter nie op die voorgrond nie. Dit is wel so dat die individuele Godshelewenis in die later stadiums van die Israelitiese vroomheid sterker profiel kry, soos by Esegiël $(14: 12-20 ; 18)$ en nog sterker by Job en Prediker 23.

Teenoor Gerleman se standpunt dat ons in sekere Ou-Testamentiese uitsprake die neerslag van 'n konsekwente en radikale individualisme kry, moet egter betwyfel word of die individualistiese denke die sterk korporatiewe lewensbenadering, wat selfs nog in die Nuwe Testament teenwoordig is ${ }^{24}$, daadwerklik verdring het. Korporatiewe en individualistiese denke hoef mekaar nie uit te sluit nie. Hulle kan in 'n gesonde en kreatiewe dialektiese verhouding tot mekaar staan. Dit is ons Westerse denke wat die individualisme verheerlik en verabsoluteer het.

Hierdie insig geld ook vir die Nuwe-Testamentiese denke, alhoewel dit onnodig is om hier uitvoerig te substansieer dat die individuele Godsverhouding in die Nuwe Testament relatief groter gewig ontvang as in die Ou Testament. Steeds bly die individuele gelowige se Godsbelewenis egter ingebed in die van die Godsvolk as geheel. 
Die derde Bybelse metafoor wat hier aan die orde gestel moet word, is die van 'n huisgesin waarin God die Vader en die gesinslede God se kinders en mekaar se broers en susters is. Ook hier het God, kragtens die feit van sy vaderskap, die inisiatief. Ook hier in die familia Dei word die liefdeskarakter van die verhouding beklemtoon. Die assosiasies van sorgsaamheid, warmte en vertroulikheid funksioneer sterk. Dit is byvoorbeeld besonder duidelik in Jeremia 3:19 en 31:9. Tog is dit nie toevallig dat hierdie metafoor sterker in die Nuwe Testament figureer nie. Dit is immers besonder geskik om die nabyheid van God en die vertroulikheid van gelowiges se Godsbelewenis te beklemtoon. Jeremias het daarop gewys dat die vertroulike gebedsaanspreke van God as "Vader" uniek aan Jesus self was en die hartaar van sy Godsverhouding uitgemaak het ${ }^{25}$. Wanneer Jesus hierdie benaming in die "Onse Vader"-gebed ook aan sy volgelinge deurgee en God in sekere uitsprake as "julle Vader" tipeer ${ }^{26}$, word hierdie vertroulike verhouding ook deel van hulle eie Godsbelewenis. Tipies hiervan is die Abba-roep van Geesvervulde Nuwe-Testamentiese gelowiges wat God met verwondering en blydskap as hulle Vader beleef (Rom 8:16; Gal 4:6). Hierdie belewenis van kind-van-God-wees gee aan die Nuwe-Testamentiese spiritualiteit 'n voorheen ongekende vertroulikheid, geborgenheid en innigheid.

Plaas ons hierdie gesinsmetafoor op sy beurt binne die raamwerk van die kollektivisme/individualisme vraagstelling, is dit opvallend dat God in die Ou Testament steeds as Vader van die Godsvolk as geheel figureer (Deut 32:6; Jer $3: 19 ; 31: 9$; Jes $63: 16 ; 64: 8$; Mal 1:6; $2: 10$ ). In die Nuwe Testament kry ons egter, naas die kollektiewe beskouing, nou ook die eksplisiete vermelding van God as Vader van die enkeling, soos blyk uit die opdrag aan die individuele gelowige om hom in die vertroulikheid van sy "binnekamer"27 tot God as sy Vader te wend. Hierdie ontwikkeling pas logies in op die relatief groter Nuwe-Testamentiese klem op die individuele Godsverhouding.

Die Pauliniese formulering wat die gelowiges se nuwe relasie tot God die sterkste uitdruk, is die talle "in Christus"-uitsprake (Rom 3:24; 6:23; 8:1,2,39; 9:1; ens). Die gelowiges is korporatief in die Christuswerklikheid opgeneem en binne hierdie nuwe relasie kan hulle nou 'n besondere verbintenis met God beleef. Hierdie selfde verbintenis kan egter ook pneumatologies uitgedruk word. Daarom kan Paulus by geleentheid ook sê dat die gelowiges "in die Gees" is (Rom 8:9).

Ons vat saam: Lewensgemeenskap met God word in die Bybel moontlik gemaak binne die ruimte van 'n vaste, deur God in genade en liefde daargestelde verhouding. Dit is nie die produk van menslike toewyding, selfkastyding, askese of kontemplasie nie. Binne hierdie verhouding waarin God se inisiatief, liefde en trou vooropstaan, word die sondegebondenheid van die mens deurbreek en ware lewensgemeenskap met Hom 'n moontlikheid. Hierdie lewensgemeenskap is nie volgens die tipies Westerse romantisering van die individualisme die "alle rindividueelste ekspressie van die allerindividueelste emosie" nie. In die Ou Testament is dit allereers 'n belewenis van God se volk, alhoewel die individuele Godsbelewenis en vroomheid hier ook 'n ruim plek ontvang. In die Nuwe Testament figureer die Godshelewenis van gemeenskap en enkeling ook binne die ruimte van 'n deur God in vrye genade en liefde geskepte nuw'e relasie wat in Christus 'n werklikheid geword het. Dit word deur sowel die metafore van die verbond, die huwelik en die huisgesin as die "in Christus"-uitsprake beklemtoon. Veral die Nuwe-Testamentiese 
Vader-kind metafoor bring egter 'n besondere element van innigheid, warmte en vertroue by.

\subsection{Metafore wat die lewensgemeenskap met God uitbeeld}

Reeds onder die vorige twee hoofde het verskillende aspekte van die daadwerklike lewensgemeenskap en omgang met God ter sprake gekom. So byvoorbeeld hou die motief van God se "woon" by sy volk reeds die aspek in van 'n blywende lewensverbondenheid. Dat hierdie "woon" God se persoonlike teenwoordigheid in die individu se daaglikse lewenswerklikheid ingesluit het, blyk uit Jesaja 57:15: God verklaar dat Hy nie net in die "hoogte" en "in die heilige plek" (NAV: "in 'n hoë en heilige plek") woon nie, maar ook by verdruktes en nederiges.

'n Ou-Testamentiese metafoor wat die blywende persoonlike lewensverbondenheid en gemeenskap met God sterk uitdruk, is die "ken van God/die Here" of die "kennis van God". Eersgenoemde uitdrukking kom veral sterk by die profete voor (Jes 19:21; 45:4-5; 52:6; Jer 2:8; 4:22; 9:6,24; 22:16; 24:7; 31:34; Eseg 28:19; Hos $2: 19 ; 5: 4 ; 6: 3 ; 8: 2 ; 13: 4)$. Laasgenoemde tree na vore in Spreuke 2:5, Jesaja $11: 2,9$ en is prominent in Hosea $(4: 1,6 ; 6: 6)$. Hierdie kennis van God is veel meer as 'n bloot kognitiewe erkenning. Dit sluit in 'n persoonlike verhouding, 'n lewensgemeenskap met God ${ }^{28}$. Om God te ken het as keersy dat God ook mense "ken". Ook hier staan die persoonlike verhoudingselement meermale op die voorgrond (Jer 1:5; Hos 13:5; Amos 3:2; Nah 1:7) ${ }^{29}$.

Die pragtige metafoor van "wandel met God", wat die priesterlike outeur in Genesis twee keer van Henog (5:22,24) en een keer van Noag (6:9) gebruik, is 'n besonder plastiese manier om die gedagte van lewensgemeenskap met God uit te druk ${ }^{30}$. Van die latere verbeeldingryke Henogspekulasies in die uitgebreide Henogliteratuur vind ons in Genesis niks nie. Heel sober en sonder enige mistieke konnotasie word die geheimenis van 'n lewe in vertroulike omgang met God geskets en as ideaalbeeld vir latere geslagte voorgehou.

Alhoewel die woordgebruik nie heeltemal dieselfde is as in Genesis nie ${ }^{31}$, kom die gedagte van 'n lewe naby aan God ook in Miga 6:8 voor. Hierdie treffende perikoop (6:6-8) vorm 'n besondere hoogtepunt in die Ou-Testamentiese vroomheidsdenke. Die Ou-Testamentiese offer as sodanig word nie afgeskrywe nie, maar die prioriteit van 'n praktiese gehoorsaamheidslewe en 'n ootmoedige omgang met God word uitgelig.

'n Derde metafoor om die innige lewensverbondenheid met God te beskryf, is diè van vriendskap. In Jesaja 41:8 en 2 Kronieke 20:7 word Abraham as "vriend" van God geteken (vgl ook Jak 2:23). In Eksodus 33 se merkwaardige beskrywing van die unieke verhouding tussen God en Moses word gesê dat God met Moses gepraat het "soos 'n man met sy vriend" ( $v$ 11). In die Wysheid van Salomo 7:27 word van die wysheid gesê dat dit van heilige mense "vriende van God en profete maak". Dit is waar dat hier ideaalbeelde geteken word. Terselfdertyd moet egter gevra word: Waarom hierdie idealisering? Is dit nie juis omdat hierdie vertrouensverhouding met God juis as navolgenswaardige lewensideaal geteken word nie?

Sekere faktore het egter meegebring dat hierdie persoonlike omgang met God nooit ontaard het in 'n eie-wees met Hom nie. Enersyds was daar die besef van God se heiligheid en gans-andersheid, en andersyds dié van die sondaar-wees van 
die mens. Die uitdrukking die "vrees van die Here", wat so 'n belangrike rol in die Ou Testament speel, het aangedui dat daar, te midde van die ervaring van God se nabyheid en toeganklikheid, nog steeds 'n diepe eerbied vir die heiligheid van God bly bestaan het. Vriezen wys daarop dat juis hierdie faktore die aantasting van die geheimenis van God se wese voorkom het ${ }^{32}$.

In die Pauliniese sleutelpassasie Filippense 3:4-14, waar die apostel aan ons 'n besondere insig gee in sy eie geestelike selfverstaan voor en na sy bekering (die oorgang geskied tussen verse 6 en 7), word die "ken-motief" as uitdrukking van 'n intens persoonlike Christusverbondenheid uitgelig ( $v$ 8,10). Dit maak die essensie uit van wat nou vir Paulus die belangrikste saak in sy lewe is. Die OuTestamentiese "God/Jahwe ken" word nou vervang met "Christus ken". Hierdie "ken van Christus" is vir Paulus so belangrik dat hy alle ander dinge as waardeloos

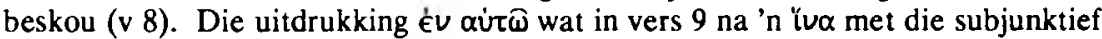
$\epsilon \dot{u} \in \epsilon \hat{\bar{\omega}}$ voorkom, is besonder interessant. Dit kan 'n gepronominaliseerde "in Christus"-uitspraak wees en so Paulus se reeds gerealiseerde nuwe posisie in Christus uitdruk, maar die "in Hom" kan ook Paulus se begeerte om in vereniging met Christus te lewe uitdruk. Die Nuwe Afrikaanse Vertaling het vir laasgenoemde gekies en vertaal "en een met Hom te kan wees". Op taalkundige en teologiese gronde is albei keuses moontlik. Die klem op die alles-oorheersende belang van 'n persoonlike verhouding met Christus is egter nie van 'n beslissing in hierdie opsig afhanklik nie. Die twee maal herhaalde "ken"-motief stel dit in ieder geval op die voorgrond.

Uiters belangrik is nog verder die insig in die dinamiese karakter van die "Christus ken". Dit blyk nie alleen uit die iva-sin in vers 9 nie, maar ook uit die infinitief tov yūual in vers 10 . Hierdie dinamiese aspek word nog verder onder-

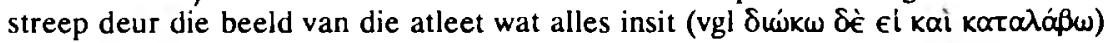
om die wenpaal te bereik ( $v 12$ ).

Van verdere belang in hierdie gedeelte is die uitwerking van die Christusgemeenskap op Paulus self. Die terminologie in verse 10-11 gee duidelik te kenne

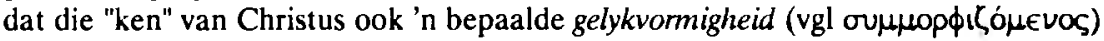
met Hom meebring. Die ware lewensverbondenheid met Christus bring mee ' $n$ ondervinding van en praktiese sigbaarmaking van Christus se opstandingskrag en 'n

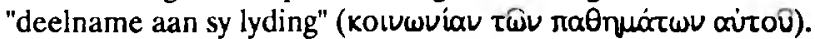

Die vraag tree nou dringend na vore of ons nie hier 'n duidelike voorbeeld van Christusmistiek by Paulus het nie. In die kerkgeskiedenis en ook in die NuweTestamentiese wetenskap is inderdaad meermale aanvaar dat Paulus in uitsprake soos dié in Filippense 3:7-14 en Galasiërs 2:20 van 'n mistieke Christus-ervaring uitgaan. Adolf Deissmann het die "in Christus"-uitsprake as sterk getuienis vir Christusmistiek by Paulus beskou 33 . Ook Albert Schweitzer het aanvaar dat Paulus 'n soort Christusmistiek voorstaan ${ }^{34}$.

Ten opsigte van 'n definiëring van wat met "mistiek" bedoel word, bestaan daar die allergrootste probleme, omdat dit in soveel nuanseringsvariasies gebruik word. Wanneer die woord "mistiek" egter verstaan word in die sin van 'n direkte wesenskontak met God waarop 'n soort "wesensversmelting" volg en waarin die mens sy identiteit inboet, moet kategories ontken word dat hierdie beskouing in die Bybel voorkom ${ }^{35}$. Die rede hiervoor lê myns insiens in die sterk Bybelse klem op die heiligheid, uniekheid en wesenlike andersheid van God. Die mens is wel beeld van God, maar nie wesensverwant aan God nie ${ }^{36}$. Daarom is werklike wesens- 
eenwording met God en die daardeur moontlik-gemaakte vergoddeliking van die mens onmoontlik ${ }^{37}$. Die Pauliniese Christusverbondenheid is nie 'n mistieke unio met Christus nie, maar 'n communio waarbinne 'n noue persoonsgemeenskap plaasvind 38 .

Paulus druk hierdie noue lewensverbondenheid ook in terme van die

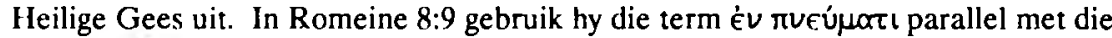
Ėv Xpı Heilige Gees in die Christene. Die Christene bevind hulle in hierdie nuwe Geesverhouding op grond van hulle geloof in Christus. Hulle het oorgegaan van die lewenswerklikheid van die oóp $\xi$ en bevind hulle nou in die nuwe lewenswerklikheid van die Gees. Maar terselfdertyd woon die Heilige Gees ook in hulle. Die apostel druk hierdie belewenis van die werking van die Gees in gelowiges se lewe by

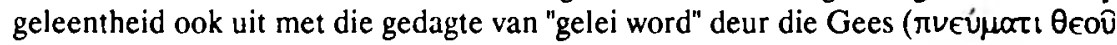
äyoutal: Rom 8:14; Gal 5:18). Die wandel-motief word ook ten opsigte van die beheersing van die Christen deur die Gees gebruik, naamlik in Galasiërs 5:16

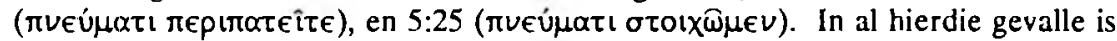
die datief $\pi v \in \cup$ ua $\iota$ instrumenteel en dui op die beherende invloed van die Gees. Deurgaans word' $n$ baie persoonlike verhouding tussen Christene en die Heilige Gees veronderstel.

Dit is belangrik om ook hier in Galasiërs 5 die dinamiese aspek raak te sien. Die "wandel deur die Gees" staan hier twee keer as opdrag, soos blyk uit die imperatief van vers 16 en die kohortatief van vers 25 . Daar rus dus op gelowiges 'n verantwoordelikheid ten opsigte van hulle verhouding met die Heilige Gees. Hierdie verantwoordelikheid sluit positief 'n openheid vir die werking van die Gees en 'n luister na die Gees (gehoorsaamheid aan die leiding van die Gees) in, en negatief die volhardende stryd teen die oápł. Die oópł waarvan Paulus hier praat wat in 'n worstelstryd met die Gees verkeer sodat die gelowiges nie ten volle kan doen wat hulle graag wil nie (v 17), is daardie stuk verset teen God, daardie nog onverowerde deel van ons ou menslike natuur wat ware spiritualiteit voortdurend bedreig en kniehalter.

Dit is in besonder in die Pastorale Briewe dat die verantwoordelikheid van gelowiges ten opsigte van 'n lewe in die regte verhouding tot God beklemtoon

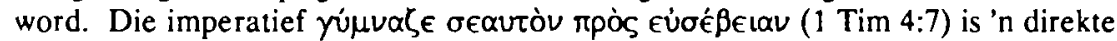
opdrag tot inoefening in die Godgewyde lewe.

Die Johannese literatuur druk die gemeenskapsverhouding tussen gelowiges en Christus/God op aangrypende wyse uit deur middel van die "bly in"uitsprake. Soos die Vader in Christus bly (Joh 14:10), so bly Christus/God in die gelowiges (Joh 15:4,5; 1 Joh 3:24; 4:12,13,15,16) en die gelowiges in Christus of in God (Joh 6:56; 15:4,5,6,7; 1 Joh 2:6,24,27,28; 3:6,24; 4:12,13,15,16). Ook die "wees in" uitdrukkings ten opsigte van die verhouding van die gelowiges tot Christus (of die Gees) kan hier bykom: Johannes 14:17,20; 1 Johannes 2:5,24,2739. Ook hierdie "bly in" of "wees in" dui nie op 'n mistieke eenwording (uniomystica) nie, maar op 'n baie persoonlike gemeenskapsverhouding ${ }^{40}$. Dat dit nie hier om 'n mistieke persoonsversmelting gaan nie, blyk onder meer uit die rol van die Goddelike

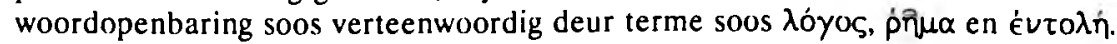
Die ontmoeting en gemeenskap met God geskied dus nie direk soos in die mistiek nie, maar via Jesus/God se spreke (vgl Joh 8:31; 15:7,10; 1 Joh 2:14,24). Ook die groot klem op die liefde wat hierdie verhouding kenmerk, wys op 'n verhouding 
tussen twee willende persone (Joh 15:9,10; 1 Joh 4:12,16).

Ook in die Johannese literatuur is daar duidelike aanduidings dat hierdie gemeenskapsverhouding nie staties is nie. Dit blyk alreeds uit die groot aantal voorwaarde-sinne wat in hierdie konteks gebruik word ${ }^{41}$. Dit is egter veral die imperatiewe van Johannes 15:4 en 1 Johannes 2:27-28 wat daarop dui dat die gelowiges aktief betrokke is by en 'n verantwoordelikheid het ten opsigte van die voortgang van die Godsgemeenskap.

Ons kan dus by Paulus sowel as "Johannes" praat van die indikatief en die imperatief van die verbondenheid met God. In Christus Jesus is dit 'n gegewe relasie, 'n geloofswerklikheid wat aan ons geskenk word. Maar terselfdertyd staan dit ook onder die imperatief: gelowiges moet werk aan hierdie verhouding. Hulle moet hulle aktief toewy aan die Here. Spiritualiteit is nie net 'n gawe nie; dit is ook 'n opdrag. Dit hou die allernouste verband met die heiliging van ons lewe, wat beide 'n gawe en 'n opgawe is.

Die "ken"-motief waaraan ons reeds in die Ou Testament en by Paulus aandag gegee het, dien ook in die Johannese literatuur op 'n heel pregnante wyse om gelowiges se persoonlike verbondenheid met God aan te dui. Dit geskied egter op tipies Johannese wyse (vgl Joh 10:14,15,27; 14:7,17; 17:3; 1 Joh 2:3,4,13,14;4:6,7)

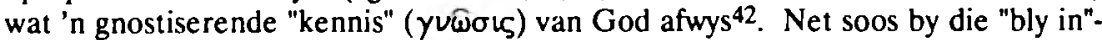
uitsprake wys die rol van die openbaring en van die geloof en liefde daarop dat dit hier geensins om 'n mistieke eenwording gaan nie ${ }^{43}$.

\section{$2.4 \quad$ Ontmoetingsmomente}

Afgesien van die verskeidenheid van wyses waarop Bybelse spiritualiteit as 'n blywende lewenswerklikheid uitgebeeld word, is ook die onderskeie ontmoetingsmomente belangrik. Hierdie ontmoetingsgeleenthede is as't ware besondere konsentrasiepunte van die ervaring van God se nabyheid. Dit is nie nodig of moontlik om nou breedvoerig op hierdie ontmoetingsmomente in te gaan nie, behalwe om hulle kortliks te vermeld.

Ons het reeds telkens gesien dat die Bybel nie 'n direkte, mistieke Godsontmoeting ken waarin 'n wesensversmelting plaasvind soos in die Hellenisme, die Gnostiek en ander geestesstrominge nie. Ook die godsdienstige ekstase waarin die mens heeltemal beheer oor homself verloor, was nie die normale patroon nie. By sekere profetiese en apokaliptiese Godsbelewenisse het ekstatiese ervaringe wel 'n rol gespeel ${ }^{44}$. Hierdie soort ervarings is egter beleef as uitsonderings en was nie sonder gevare nie $\mathrm{e}^{45}$. Die normale ontmoeting met God het geskied langs die weg van aanspreke deur die woord van God, in kultiese belewenisse waar gelowiges in groepverband of individueel "voor die Aangesig van God" verkeer het, en in persoonlike gebed. Die Psalms bied aan ons 'n aangrypende spieëlbeeld van die gebedsvroomheid van Ou-Testamentiese bidders 46. Talle Psalmuitsprake spreek van 'n intens persoonlike verhouding met Jahwe, waarin dit primêr om Jahwe, om die vreugde van sy nabyheid gaan. Die digter van Psalm 16 kan byvoorbeeld aan God sê dat hy aan Hom behoort en dat daar vir hom niks goeds is nie, behalwe by God (v 2). Die grootste wens van die digter van Psalm 27 is om al sy dae in die Here se woning deur te bring en sy "lieflikheid" te aanskou (v 4).

In die uitspraak "Jahwe is my deel", met sy lang tradisiegeskiedenis ${ }^{47}$, het Levitiese kringe die hart van hulle geloofslewe saamgevat (Ps 16:5; 73:26). Te 
midde van alle ontbering, gevaar en aanvegting was dit die wete van God se nabyheid wat sin aan die lewe gegee het:

Daar is niks in die hemel

of op die aarde

wat vir my meer beteken as $\mathrm{U}$ nie.

$\mathrm{Al}$ is ek afgetakel na liggaam en gees,

God is my sterkte;

aan Hom behoort ek (letterlik God is my deel) vir altyd...

Maar wat my aangaan,

dit is vir my goed

om naby God te wees. (Ps 73:25-26,28:NAV).

By talle Psalmuitsprake sal ons in gedagte moet hou dat ook individueel-klinkende formulerings in werklikheid hinne liturgiese konteks verstaan moet word ${ }^{48}$. Die "ek"-uitsprake word in kulties-kollektiewe verband uitgespreek soos ook vandag in kerklike gemeentesang geskied4?. Dit neem egter die feit nie weg dat gelowiges deur alle tye juis in hierdie tipe kulties-kollektiewe uitsprake hulle eie spirituele ervarings kon terugvind en uitdruk nie. Joachim Jeremias het byvoorbeeld op treffende wyse daaraan herinner hoe Jesus self op die vooraand van sy kruisiging, by die sing van die Hallel (vgl Ps 113-118), uit die woorde van Ps $118 \mathrm{krag}$ en versterking moes geput het ${ }^{50}$ :

Ek sal nie sterwe nie, ek sal lewe en van die dade van die Here getuig...

Die klip wat deur die bouers afgekeur is, juis hy het die belangrikste klip in die gebou geword.

Dit is deur die Here gedoen

en is 'n wonder in ons oë... (NAV: Ps 118:17,22-23)

In die tussen-testamentêre tydvak vind ons, naas die individuele gebed en gebedshandelinge in en rondom die tempel, nou ook gebedsontwikkeling binne die groeiende sinagogale sisteem. Jeremias het aangetoon hoe die Palestynse wêreld waarin Jesus opgegroei het, 'n uitgebreide gebedspraktyk geken het ${ }^{51}$.

In die Nuwe-Testamentiese gemeentes geskied die ontmoeting met God deur woord en gebed, terwyl die werking van die Heilige Gees van deurslaggewende belang is. Soos in die Ou Testament is die gesagvolle woord, nou gespreek deur Jesus Christus en sy gevolmagtigdes, die beslissende kommunikasiemedium. Opvallend is die hesondere klem wat nou gelê word op die gemeente en individue se verantwoordelikheid om te bid (Luk 11:5-13; 18:1-8; Rom 12:12; Filip 4:6; Ef 6:1820; Kol 4:2; Heb 10:19-22; ens). Die uiters belangrike rol van die Heilige Gees in die gebed blyk uit 'n gedeelte soos Romeine 8:26-27 waar die Gees beskryf word as die Een wat as't ware die onvermoë van dic gelowige om sy versugtinge te verwoord opvang, en sy gebed "oorncem" voor God se aangesig (vgl Efes 6:18).

Die menslike reaksie in hierdie ontmoetingsmomente word uiteraard bepaal deur die feit dat hier 'n persoonsontmoeting tussen God en mens plaasvind, met ander woorde hierdie reaksie word bepaal deur wie en wat God is en deur wie 
en wat die mens is. Omdat God die Verhewene, die Almagtige en die Algoeie is, en die mens die kleine, die afhanklike, die begenadigde, word hierdie ontmoetings gekenmerk deur menslike lofprysing en aanbidding. Omdat God die Heilige en die mens sondaar is, word die ontmoeting met God voorts gekenmerk deur sondebesef en skuldbelydenis ${ }^{52}$. Daarom is nederigheid een van die mees tipiese kenmerke van Bybelse spiritualiteit ${ }^{53}$. Dat egte spiritualiteit geen ek-gerigtheid in die gebed toelaat nie, blyk ook uit die besondere rol wat intersessie in Bybelse gebede speel. Ons kry dit onder meer as tiperend van Abraham (Gen 18:16-33; 20:7), Moses (Eks $8: 8,9,28-31 ; 10: 17-18 ; 32: 30-32 ; 34: 8-9$; Num 12:13; 14:13-19; Deut 9:18-20, 25-29; ens), Samuel (1 Sam 7:5,8; 12:19,23), Job 42:8,10; Jeremia 7:16; 11:14; 14:11 vgl 32:16-20; 42:1-4; Jesus Christus self (Luk 22:31-32; Joh 17; Heb 7:25) en Paulus (Filip 1:9-11; 2 Tes 1:11; Efes 1:15-23; 3:1, 14-19; Kol 1:9-14). In die Nuwe Testament word dit trouens 'n opdrag vir gelowiges (Mat 5:44; Kol 4:3; 1 Tes 5:25; Jak 5: 14-16; ens).

Kenmerkend van hierdie spiritualiteit is sy byna skokkende eerlikheid. Ou-Testamentiese gelowiges het meermale die geloofsmoed, maar ook die geloofsvertroue, om met God te worstel oor sy optrede of gebrek aan optrede in hulle belang, oor die onreg wat Hy oogluikend toelaat (Ps 73; ens; vgl veral die "hoe lank?"-vrae: Job 7:19; Ps 6:4; 13:2-3; 35:17; 74:9-10; 78:5). Hulle twis selfs met God soos Job, Jeremia (15:17-18), Jona (4:1-3). Vriezen beklemtoon met reg dat daar deur die Ou Testament "een frisse wind van geestelijke vrijheid" waai. Die "vrees van die Here" het geen slaafse onderdanigheid beteken nie ${ }^{54}$.

'n Verdere saak wat hier kortliks aandag moet kry, is die wyse waarop in die Ou- sowel as die Nuwe Testament 'n verband gele word tussen die ontmoeting met God en vreugde. Godsgemeenskap en blydskap hoort dwarsdeur in die Bybel saam 55 . Daarom is ook die feeste en die offermaaltye, waar die gemeenskap met God op besondere wyse beleef is, gekenmerk deur vreugde ${ }^{56}$. Wanneer Paulus die uitdrukking "bly wees in die Here" gebruik (Filip 3:1; 4:4,10), impliseer dit duidelik die verband tussen Godsgemeenskap en blydskap. Dit is ook nie sonder rede nie dat die nagmaalgeleenthede van die eerste gemeente (=die "broodbrcking") volgens

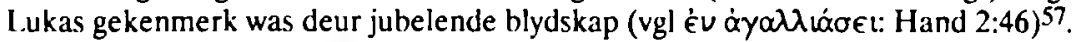

Etiese implikasies ${ }^{58}$

Uit verskillende Ou-Testamentiese sowel as Nuwe-Testamentiese uitsprake blyk dat die spiritualiteit waarom dit hier gaan, geensins 'n eksklusief na binne gerigte karakter besit nie. Dit stempel gelowiges se lewenstyl en lewenspraktyk op 'n heel besondere wyse. Reeds die "wandel met God"-metafoor wys daarop dat dit hier om 'n lewe gaan wat bepaal word deur die lewensverbondenheid met God. Daar is dus "n haie nou verband tussen die "wandel met God" en die "wandel voor God se aangesig" (Gen 17:1; 24:40; 48:15; ens). In eersgenoemde val die klem op die gemeenskap met God, in laasgenoemde op die verantwoordelikheid teenoor Hom 5". Die verkeer "voor die Aangesig van (God" impliseer 'n gehoorsaamheidsbestaan coram Dei. Dit is sekerlik nie sonder betekenis dat die term "die vrese van die Here" in die Wysheidsliteratuur geheel en al met ons konkrete lewenspraktyk te make het nie.

Nêrens in die Nuwe Testament word die etiese aspek van die lewens. gemeenskap met God treffender hoklemtoon as in die Johannese geskrifte nie. In 
Johannes 15 is die "bly in Christus" die geheim van vrug-dra (15:1-8). In sy belangrike artikel oor die etiek van die Johannesevangelie ${ }^{60}$ het $\mathrm{J} G$ van der Watt gewys op die sleutelrol van Johannes 15 vir die verstaan van die Johannese etiek. 1 Johannes 2:6 stel dit prontuit: "Wie beweer dat hy in Hom bly, behoort self ook te lewe soos Hy gelewe het" ( $\mathrm{vgl}$ ook 3:6,24). Hierdie selfde verband tussen Godsgemeenskap en etiek tree ook sterk na vore in Galasiërs 5. Dit is juis die "wandel deur die Gees" wat die gelowiges in staat stel om nie die natuurlike begeerte te laat seëvier nie en die vrug van die Gees voort te bring (Gal 5:16-26). In Bybelse spiritualiteit vorm lewensgemeenskap met God en lewensheiliging 'n eenheid.

'n Baie interessante Bybelse ontwikkeling ten opsigte van die verhouding tussen die kultus waar die lewensgemeenskap met God besonderlik ervaar is en lewenspraktyk is die voortgaande "etisering" van kultiese motiewe. Hiermee word bedoel dat kultiese motiewe steeds meer vergeestelik is en oorgedra is na die lewenspraktyk. Lof aan God word beskryf as 'n "offerande" (Ps 50:23). Gebed word 'n "wierookoffer" (Ps 141:2), ensomeer ${ }^{61}$. Hierdie tendens tot vergeesteliking beteken nie dat Ou-Testamentiese skrywers die kultus noodwendig afgeskryf het nie62. Dit wil veel eerder beteken dat daar, ten minste aanvanklik, 'n eng verband gelê is tussen kultiese belewenis en persoonlike vroomheidslewe. Hierdie spiritualisering en etisering van kultiese motiewe gaan nog sterker voort in die Nuwe Testament ${ }^{63}$. Die Christelike gemeente (1 Kor 3:16-17; 2 Kor 6:16; Ef 2:21), ja selfs die Christen se liggaam (1 Kor 6:19), is 'n tempel van God. Die toegewyde lewe van gelowiges word nou "lewende en heilige offers aan God" (Rom 12:1-2). Hicrdie toewyding van onsself is nie opsioneel nie; dit is 'n opdrag. Heiliging van die "alledaagse" is deel van die Nuwe-Testamentiese "erediens".

\section{$2.5 \quad$ Lewensgemeenskap en eskatologie}

Aangesien alle Godsgemeenskap in die hier en nou 'n sekere beperking, 'n bepaalde gebrokenheid vertoon, is dit begryplik dat gelowiges se inherente behoefte aan die volkome Godsgemeenskap duidelik sy spore in die ontwikkelende eskatologiese denke gelaat het.

Hierdie feit kan goedskiks aan die ontwikkeling van die idee van die eskatologiese vreugdemaaltyd geïllustreer word. Hierdie maaltyd, wat die volmaakte samesyn van God met sy mense moes uitdruk, word in alle pleroforie in die Jesaja-Apokalips (kyk Jes 25:6-12) en in die Vroeg-Jodedom geskilder ${ }^{64}$. Dit word egter ook in die Nuwe Testament, by name by die instelling van die Nagmaal opgeneem ${ }^{65}$. Eenmaal, in die eschaton, sal die Godsgemeenskap, wat nou nog so gebroke is, volkome wees.

Wanneer Paulus sy eie verwagting vir die lewe onmiddellik na die dood tipeer, noem hy dit 'n "wees met Christus" (Filip 1:23). As hy praat van die gelowiges se situasie na die paroesie, verklaar hy: "En so sal ons altyd by die Here wees" ( 1 Tess 4:17 (vgl 5:10). En die boek Openbaring beklemtoon dat die essensie van dic nuwe Jerusalem daarin sal bestaan dat ons Godsgemeenskap dan volkome sal wees: "Kyk, die woonplek van God is nou by die mense. Hy sal by hulle bly; hulle sal sy

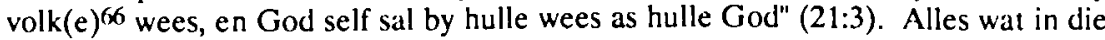
voorafgaande oor die Godsgemeenskap in Israel en binne die Nuwe-Testamentiese kerk gesê is, word hier in wese saamgevat, maar nou binne eind-eskatologiese kader. 
Ware Bybelse spiritualiteit het dus altyd 'n eskatologiese spits. Die deur menslike sonde gebroke Godsverbondenheid hunker na die volkome Godsbelewenis van die voleinding. Ons huidige ervaring van God se teenwoordigheid bring ons telkens by die grens van ons menswees. Daarom moet dit, kragtens sy wese, uitreik na die volmaakte, ewige wees by God. Okke Jager het hierdie korrelasie pragtig verwoord in 'n speels-blye gediggie oor Henog se spontane verhouding met God ${ }^{67}$ ?

En God en Henoch waren kameraden.

Dus God kwam vaak bij Henoch op bezoek.

Nadat zij samen voor de kwaden baden,

Las God een stukje uit Zijn eigen boek.

Eens zei de Here op een mooie morgen:

"Zeg, Henoch, ga je mee een eindje om?

Je vrouw zal dan wel voor het eten zorgen."

En Henoch zei: "'t Is goed hoor, God, ik kom!"

Hij durfde wel zijn kindren achterlaten.

Hij riep: "Tot straks!" en deed de deur op slot.

$\mathrm{Zij}$ hadden samen heel veel te bepraten.

Dus Henoch wandelde aldoor met God.

De vogels wisten wel, voor Wie zij zongen.

En alle bloemen kwamen nu aan bod.

De herten kwamen dichtbij met hun jongen.

En Henoch wandelde aldoor met God.

Totdat opeens: "o, Heer!" zei hij geschrokken,

"Wij zijn al veel te ver: daar staat Uw Huis!

't Is lang geleden al, dat wij vertrokken...

Hoe kom ik ooit alleen weer veilig thuis?"

"Och Henoch", zei de Heer, "om tijd te winnen,

-Je komt toch later bij Mij wonen, -zeg,

Ga nu dan maar gelijk met Mij naar binnen!"

En Ilenoch was niet meer: God nam hem weg".

NOTAS:

$1 \quad$ Indringende besprekings van die begrip "spiritualiteit" kan nagelees word by D J Smit, "Kan spiritualiteit beskryf word?", NGTT 30 (1989), 85-87; W D .Ionker, "Die eie-aard van die Gereformeerde spiritualiteit", NGTT 30 (1989), 288. Jonker, $a w, 1989,288$, wys tereg daarop dat die gebruik van die Griekse woord $\epsilon \dot{v} \sigma \epsilon \beta \epsilon i \alpha$ in die Nuwe Testament die naaste kom aan wat ons bedoel met spiritualiteit. Die beste vertaling vir hierdie woord sou wees "godsvrug" of "toewyding aan God". Die Latynse ekwivalent hiervoor is die woord pietas. In sy belangrike artikel "Spiritualiteit as Bybelse vroomheid in die teologie en gemeentlike hediening", Praktiese Teologie in Suid-Afrika 4 (1989), 1-17, 
neem D J Louw die begrip $\epsilon \dot{U} \sigma \epsilon \beta \epsilon i \alpha$ as die vertrekpunt vir sy argumentvoering. Die saak van Bybelse spiritualiteit gaan egter veel wyer.

2 In die Nederduitse Gereformeerde Teologiese Tydskrif alleen het daar oor die afgelope sowat vyf jaar reeds die volgende artikels oor spiritualiteit verskyn: D J Smit, "Wat is gereformeerde spiritualiteit?", NGTT 29 (1988), 182-193; D J Smit, $a$ w, 1989, 83-94; W D Jonker, $a w, 1989,288-299$; H van der Merwe, "Biblical spirituality", NGTT 30 (1989), 468-475; W D Jonker, "Spiritualiteit en Godsverduistering", NGTT 33 (1992), 170-178; Binne die konteks van die Nederduitse Gereformeerde Kerk moet hier nog bykom die artikel van D J Louw, hierbo in voetnoot 1 aangehaal.

$3 A w, 1989,289$. Oor die oplewing in die soeke na transendensie in die algemeen, vergelyk D J Louw, $a w, 1-2$.

4 Te wete Studies in Spirituality, uitgegee deur die Titus Brandsma Instituut (Nijmegen) by Pharos, Kampen.

5 Vergelyk H Bandt "Verborgenheit Gottes", $R G G$ VI, Tübingen 3 1957ev, kol 1256.

$6 \quad$ Vergelyk ook Jesaja 32:6. A Weiser, Die Psalmen (ATD Band 14/15), Berlin 1955, 102-103, beweer tereg dat dit in Psalm 14 nie om 'n teoretiese Godsverloëning gaan nie, maar om 'n praktiese ateïsme, "der dem Anspruch der Gotteswirklichkeit im Leben auszuweichen sucht."

7 Volgens W Holsten, "Materialismus I Religionsgeschichtlich", $R G G$ IV, Tübingen $31957 \mathrm{ev}$, kol 798, kry ons die eerste spore van teoretiese materialisme by die Griekse denker Demokritos (5de - 4de eeu vC), maar selfs hy ontken nie sonder meer die bestaan van die gode nie.

8 So A S van der Woude, kol 446-447. Vergelyk ook Jesaja 63:9; Deuteronomium 4:37; Klaagliedere 4:16.

9 Van der Woude, $a w, 454-458$. Tereg sê Th C Vriezen, Hoofdlijnen der theologie van het Oude Testament, Wageningen ${ }^{3} 1966,228$, dat die uitdrukking "aangezicht Gods" God se genadige nabyheid aandui. Soos bekend het Vriezen die idee van gemeenskap met God as die kern van die hele Ou-Testamentiese Godsopenbaring beskou.

10 Van der Woude, ibidem.

11 Van der Woude, $a w, 452-453$

12 Vergelyk Vriezen, $a w, 225-226$.

13 Kyk hieromtrent A R Hulst, שכן wohnen, THAT II, München/Zürich 1976, kol 906-909. 
Midrasch II, München 21966, 314; Hulst, $a w$, kol 909.

15 C Westermann, "Gebet II. Im AT", RGG II, Tübingen 31957 ev, kol 1213.

16 Westermann, $a w$, kol 1216.

17 W Eichrodt, Theologie des Alten Testaments I-II, Stuttgart ${ }_{1964 .}$

18 Vergelyk J Hempel, "Bund II. Im AT", RGG I, Tübingen ${ }^{3} 1957$ ev, kol $1513-$ 1516. Ook in die tussentestamentêre tydvak, byvoorbeeld by Qumran, speel die verbond 'n belangrike rol.

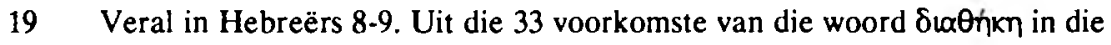
Nuwe Testament verskyn 17 in Hebreërs.

20 Vergelyk G von Rad, Theologie des Alten Testaments I, München 1966, 143149; Hempel, $a w, 1513-1516$.

21 Von Rad, ibidem; Hempel, ibidem.

22 Von Rad, $a w, 146$.

23 G Gerleman, "Gemeinschaft und Individuum II. Im AT", RGG II, Tübingen $1957 \mathrm{ev}, \mathrm{kol}$ 1351-1355. Die individuele klaagpsalms kan egter nie sonder meer as blote individuele ontboesemings verstaan word nie - Gerleman, $a w$, kol 1354: "Der Israelit ist im Kultus nicht mit seinen persönlichen Ergüssen hervorgetreten, sondern hat sich als Glied einer Gemeinde verstanden."

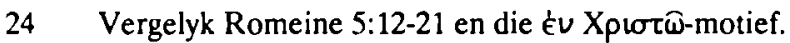

25 J Jeremias, "Abba", in: Abba. Studien zur neutestamentlichen Theologie und Zeitgeschichte, Göttingen 1966, 33-67. J Jeremias, Neutestamentliche Theologie, Gütersloh 1971, 67-73.

26 J Jeremias, $a w, 1966,64-67 ; a w, 1971,176-180$.

27 Matteus 6:6. Volgens Jeremias, a $w, 1971,187$, moet die Griekse woord

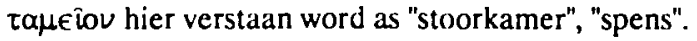

28 Vergelyk W Schottroff, רךע erkennen, THANT I, München/Zürich 1971, kol 682-701, veral 690: Dit gaan nie bloot om die kognitiewe aspek, om 'n suiwer denkhandeling nie, maar om 'n kennis wat sigself "im praktischen Umgang mit den Objekten des Erkennens verwirklicht." Ook Vriezen, $a w$, 168, beklemtoon dat hierdie "kennis" gemeenskap met God impliseer. Dit is daarom ook geen blote verstandskennis nie, maar 'n kennis van die hart.

29 Schottroff, $a w, \mathrm{kol} 692$.

30 A van Selms, Genesis deel 1 (De Prediking van het Oude Testament), Nijkerk 1967, 90-99; G von Rad, Das erste Buch Mose (ATD 2-4), Berlin 1955, 56-57.

31 Miga gebruik die werkwoord 
in plaas van $\mathbf{n}$.

$32 \quad A w, 169-171$.

33 A Deissmann, Paulus, Tübingen 21925.

34 A Schweitzer, Die Mystik des Apostels Paulus, Tübingen 1930.

35 R Bultmann, "Mystik IV. Im NT", RGG IV, Tübingen $31957 \mathrm{ev,} \mathrm{kol} \mathrm{1243,} \mathrm{kan}$ derhalwe kategories beweer: "Der Gottesglaube und die Frömmigkeit des NT sind keine Mystik".

36 Die uitspraak wat die naaste hieraan kom, is 2 Petrus 1:4 waar daarvan sprake is dat die gelowiges "deelgenote kan word van die goddelike natuur". Hierdie is egter nie 'n ontologiese uitspraak nie, maar dit gaan, soos uit die konteks blyk, om 'n moreel-etiese gelykvormigwording. Die latere Joodse denke ken wel 'n soort mistiek, maar dié het sy eiesoortige kenmerke - oorsig by S Cohen, "Mystik III. Jüdische Mystik", RGG IV,Tübingen $1957 \mathrm{ev,} \mathrm{kol}$ 1241-1243.

37 Vriezen, $a w, 187$, wys daarop dat die Ou Testament deurgaans die oudoosterse idee dat die mens uit godebloed voortkom en derhalwe wesensverwant is aan die gode, skerp afwys.

38 Bultmann, $a w, 1957$, kol 1244, wys tereg 'n mistiese verstaan af. Hy wys daarop dat hierdie 'n geloofsverhouding is.

39 Die "wees-in" formulering word ook van die verhouding tussen Christus en die Vader gebruik: Johannes 10:38; 14:11; 17:21; 1 Johannes 2:3,5; 5:20.

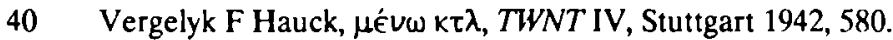

41 Kyk Johannes 15:6,7,10, ens.

42 R Bultmann, $\gamma$ wwóokw, 7WNT I, Stuttgart 21957, 712; R Snackenburg, Das Johannesevangelium I (HThKNT IV), Freiburg/Basel/Wien 1967, 152. Laasgenoemde verklaar dat die Johannesevangelie hom onder meer rig teen die gnostiese aanspraak om deur kennis en aanskoue "unmittelbare Gottesgemeinschaft" te verkry.

43 Bultmann, $a w, 1957,711-713$; Schnackenburg, $a w, 142-143,152,319-320$; ens.

44 G von Rad, $a w$ I, 1966, 69-72. Vergelyk byvoorbeeld 1 Sam 10:10-11. So ook visioner-apokaliptiese belewenisse soos die wat in 2 Korintiërs 12 en die boek Openbaring gereflekteer word.

45 Vergelyk Paulus se ontmoediging van 'n onbeheersde, ekstaties-beofende gebedsglossolalie in 1 Korintiërs 14:13-17.

$46 \quad$ Kyk Von Rad, $a w$ I, 1966, 412-414. 
48 Vergelyk Von Rad, idem, 411-412.

49 Kyk byvoorbeeld, om maar net een te noem, Gesang 228:

"Ek het toe wilde storms gewoed het, diep onder vaste Rots gevind..."

50 J Jeremias, Die Abendmahlsworte Jesu, Göttingen 31960, 246-247.

51 Jeremias, $a w, 1966,67-73 ; a w, 1971,180-183$.

52 Paradigmaties in hierdie opsig is Jesaja se skuldbelydenis wanneer hy die heiligheid van God ervaar (Jes 6). Kyk verder veral 1 Konings 8:33-36; Esra 9:6-15; Nehemia 1:6-7; 9:3-19; Daniël 9:3-19; Lukas 11:4 par Matteus 6:12; Lukas 18:9-14.

53 So tereg Vriezen, a $w, 312$. Wat die Nuwe Testament betref kan maar net herinner word aan die wyse waarop Paulus alle menslike "roem" striem - $\mathbf{R}$

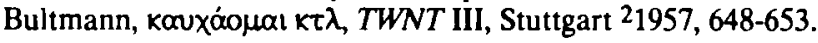

$54 \quad A w, 311$.

55 Vergelyk my proefskrif Der Aspekt der Freude im urchristlichen Abendmahl, Winterthur 1965, 13 ev, 53-56.

56 Du Toit, idem, 14-15, 53-54.

57 Du Toit, idem, 103-139.

58 Soos aan die begin van hierdie artikel in voonitsig gestel is, beperk ek my tot die eerste van die drie gemelde aspekte van spiritualiteit. Ek vind dit egter noodsaaklik om tog te beklemtoon dat die neiging tot verinnerliking van spiritualiteit ten koste van lewenstyl en lewenspraktyk onbybels is.

$59 \quad$ Kyk Van Selms, $a w, 96$.

60 J G van der Watt, "Julle moet mekaar liefhê: Etiek in die Johannesevangelie", Scriptura S9a(1992), 74-96.

61 Vergelyk Von Rad, a $w$ I, 1966, 380,409,414-416 ten opsigte van die vergeesteliking van kultiese motiewe in die Ou Testament.

62 Von Rad, idem, 380-382.

63 H Wensckewitz het 'n uitvoerige monografie oor hierdie interessante en uiters belangrike fenomeen geskrywe: "Die Spiritualisierung der Kultusbegriffe", АГГЕ $\Lambda \mathrm{O} 4$ (1932), 70-230.

64 Kyk by Du Toit, $a w, 58-62$. Vriezen, $a w, 221-222$ lig ook die eschaton uit as die voltooiing van die Godsgemeenskap. 
65 Du Toit, idem, 76-101.

66 Dit is tekskrities omstrede of die enkelvoud of meervoud hier gelees moet word. In die lig van die Ou-Testamentiese uitsprake waarop hier gesinspeel word, meen ek moet die enkelvoud die voorkeur kry.

67 "Worden als een kind", aangehaal deur J H S Smit, Ambassadeurs, Den Haag 1956, 31-32. Slegs die laaste gedeelte van die gedig word hier weergegee. 